\title{
Effects of tonic inhibition on a cortical neuronal population: implications for general anesthesia under propofol
}

\author{
Laure Buhry ${ }^{*}$, Axel Hutt \\ From Twenty Second Annual Computational Neuroscience Meeting: CNS*2013 \\ Paris, France. 13-18 July 2013
}

Anaesthetic propofol, commonly used for general anaesthesia, is known to bind to GABAA receptors [1]. It affects both synaptic and extra-synaptic receptors [2]; inducing a phasic inhibition in the first case and tonic inhibition in the latter case [3]. The effects of phasic inhibition on neuronal populations have been extensively studied, including in the case of propofol-anesthesia; however the influence of tonic inhibition on neuronal population remains an open question and changes in EEG recordings of anesthetized animals cannot be completely explained by phasic inhibition. This is the case for phenomena that appear in occipital recordings and also correlated with the loss of consciousness. Contrarily to frontal recordings that show increased alpha-rhythms $(8-12 \mathrm{~Hz})$ that can be modeled with phasic inhibition [4], occipital EEGs exhibit a) a decrease of alpha rhythms concurrently to b) an increase of slow delta rhythms $(0-4 \mathrm{~Hz})$. Our question is then: Can tonic inhibition elicit a) and b) in a cortical population of neurons?

To answer this question, we built a model of cortical population made of 750 excitatory and 250 inhibitory neurons whose dynamics resemble those found in biological neurons. Excitatory cells are modeled by a leaky-integrateand-fire model of pyramidal neurons [5] and inhibitory cells by a Morris-Lecar model [6]. The cells are connected by exponential synapses with time constants of $5 \mathrm{~ms}$ for excitatory synapses and $20 \mathrm{~ms}$ for inhibitory ones. Tonic inhibition is represented by a maximal conductance and an equilibrium potential close to the resting state of the cell.

We show with our minimal model of a cortical assembly that the peak in the power spectrum of the mean membrane voltage of excitatory cells, whose spiking frequency originally is about $11 \mathrm{~Hz}$ without tonic inhibition, shifts towards slower frequencies with increasing tonic inhibition. This result is similar to occipital EEG recordings under propofol anesthesia. However, the amplitude of the power spectra diminishes drastically, more so than in biological recordings, in the presence of tonic inhibition compared to without tonic inhibition. This may indicate that tonic inhibition is not the only occurrence responsible for the increase in amount of delta oscillations, but that thalamic inputs may help maintaining slow cortical occipital activity under general anesthesia. We are thus planning for future works to include interactions in our model between cortical and thalamic populations.

\section{Acknowledgements}

Axel Hutt acknowledges the funding from the European Research Council for support under the European Union's Seventh Framework Programme (FP7/2007-2013)/ERC grant agreement No. 257253.

Published: 8 July 2013

\section{References}

1. Kitamura A, Marszalec W, Yeh JZ, Narahashi T: Effects of halothane and propofol on excitatory and inhibitory synaptic transmission in rat cortical neurons. J Pharmacol Exp Therap 2003, 304:162-171.

2. Brickley SG: Are Extrasynaptic GABAA Receptors Important Targets for Sedative/Hypnotic Drugs? I Neurosci 2012, 32:3887-3897.

3. Mody I: Distinguishing between $G A B A(A)$ receptors responsible for tonic and phasic conductances. Neurochem Res 2001, 26:907-913.

4. Ching S, Cimenser A, Purdon PL, Brown EN, Kopell NJ: Thalamocortical model for a propofol-induced -rhythm associated with loss of consciousness. Proc Natl Acad Sci 2010, 107(52):22665-70.

5. London M, Larkum ME, H“ausser M: Predicting the synaptic information efficacy in cortical layer 5 pyramidal neurons using a minimal integrateand-fire model. Biol Cybern 2008, 99:393-401.

* Correspondence: laure.buhry@inria.fr

NEUROSYS team, INRIA Nancy - Grand Est, Villers-lès-Nancy, 54600, France 
6. Borisyuk A, Rinzel J: Understanding neuronal dynamics by geometrical dissection of minimal models. In Models in Neurophysics 2005. Proc. Les Houches Summer School;M. 2003:19-52.

doi:10.1186/1471-2202-14-S1-P178

Cite this article as: Buhry and Hutt: Effects of tonic inhibition on a

cortical neuronal population: implications for general anesthesia under propofol. BMC Neuroscience 2013 14(Suppl 1):P178.

Submit your next manuscript to BioMed Central and take full advantage of:

- Convenient online submission

- Thorough peer review

- No space constraints or color figure charges

- Immediate publication on acceptance

- Inclusion in PubMed, CAS, Scopus and Google Scholar

- Research which is freely available for redistribution

Submit your manuscript at www.biomedcentral.com/submit 